\title{
HUBUNGAN STATUS GIZI DENGAN PRESTASI BELAJAR SISWA SEKOLAH DASAR DI KECAMATAN MODOINDING
}

\author{
${ }^{1}$ Vini Maleke \\ ${ }^{2}$ Adrian Umboh \\ ${ }^{2}$ Vivekenanda Pateda
}

\author{
${ }^{1}$ Kandidat Skripisi Fakultas Kedokteran Universitas Sam Ratulangi Manado \\ ${ }^{2}$ Bagian Ilmu Kesehatan Anak Fakultas Kedokteran Universitas Sam Ratulangi Manado \\ Email: malekevini@gmail.com
}

\begin{abstract}
Nutrition is needed for growth and development, energy, thinking, and physical well-being. Selection of proper nutrition will optimize growth and brain development. This study aimed to determine the relationship of nutritional status and academic achievement of elementary school students in Modoinding. This was a descriptive analytical study with a cross sectional design. The nutritional status was based on BMI value meanwhile the academic achievement was based on school reports. Samples were 114 students. Data were analyzed by using univariate and bivariate analyses as well as ANOVA F test. The results showed that there was no significant relationship between nutritional status and academic achievement with a p value $=0.792$. Conclusion: There was no significant relationship between nutritional status and academic achievement among the elementary students in Modoinding.
\end{abstract}

Keywords: nutritional status, achievement

\begin{abstract}
Abstrak: Gizi dibutuhkan anak sekolah untuk pertumbuhan dan perkembangan, energi, berpikir, serta daya tahan tubuh. Gizi yang berkualitas akan mengoptimalisasikan pertumbuhan dan perkembangan otak. Penelitian ini bertujuan untuk mengetahui hubungan status gizi dan prestasi belajar siswa Sekolah Dasar Kecamatan Modoinding. Penelitian ini bersifat dekriptif analitik dengan desain potong litang. Status gizi dan prestasi dilihat berdasarkan nilai IMT dan hasil rapor. Jumlah sampel sebanyak 114 siswa. Data dianalisis secara univariat dan bivariat dengan uji anova F. Hasil analisis data memperlihatkan tidak terdapat hubungan bermakna antara status gizi dan prestasi belajar siswa dengan nilai $\mathrm{p}=$ 0,792. Simpulan: Pada siswa Sekolah Dasar Kecamatan Modoinding tidak terdapat hubungan bermakna antara status gizi dan prestasi belajar.
\end{abstract}

Kata kunci: status gizi, prestasi

Keberhasilan pembangunan suatu bangsa ditentukan oleh ketersediaan sumberdaya manusia (SDM) yang berkualitas, yaitu SDM yang memiliki fisik kuat, kesehatan yang prima, serta cerdas. Hal ini sangat ditentukan oleh status gizi yang baik, dan status gizi yang baik ditentukan oleh jumlah asupan pangan yang dikonsumsi. Bila gizi kurang dan gizi buruk terus terjadi, keduanya dapat menjadi faktor penghambat dalam pembangunan nasional. $^{1}$

Anak usia sekolah pada masa perkembangannya sering mengalami masalah gizi. $^{2}$ Masalah gizi adalah gangguan kesehatan dan kesejahteraan seseorang, kelompok orang, atau masyarakat akibat adanya ketidakseimbangan antara asupan (intake) dengan kebutuhan tubuh akan makanan dan pengaruh interaksi penyakit. ${ }^{3}$ Masalah gizi utama di Indonesia masih didominasi oleh 
masalah gizi kurang energi protein (KEP), anemia defisiensi besi, gangguan akibat kekurangan yodium (GAKY), dan kurang vitamin A (KVA). Disamping itu faktor yang memengaruhi keadaan gizi yaitu konsumsi makanan dan tingkat kesehatan. ${ }^{4}$

Gizi dibutuhkan anak sekolah untuk pertumbuhan dan perkembangan, energi, berpikir, beraktivitas fisik, dan daya tahan tubuh. $^{5}$ Gizi yang berkualitas sangat penting karena pada usia tersebut anak mengalami tumbuh kembang yang pesat. ${ }^{2}$

Rendahnya status gizi anak akan membawa dampak negatif pada peningkatan kualitas sumber daya manusia, walaupun belum konklusif namun diyakini bahwa kurang gizi kronis berhubungan erat dengan pencapaian akademik murid sekolah yang semakin rendah. Saat ini diperkirakan sekitar 50\% penduduk di Indonesia atau lebih dari 100 juta jiwa mengalami beraneka masalah kekurangan gizi, yaitu gizi kurang dan gizi lebih. ${ }^{6}$

Word Food Program (WFP) dan UNESCO menemukan anak usia sekolah dasar di seluruh dunia sekitar 72 juta tidak sekolah pada tahun 2007, dan 60\% mengalami gizi kurang pada tahun $2008 .{ }^{2}$ Di Sulawesi Utara angka kejadian stunting berdasarkan Riskesdas 2007 yaitu 31,2\% dan berdasarkan Riskesdas 2010 menurun menjadi $27,7 \%{ }^{7}$

Masalah kurang konsumsi gizi harus di atasi sejak dini, kalau menginginkan anakanak Indonesia tumbuh dan berkembang dengan baik. Dalam jangka panjang kurang gizi akan mengakibatkan hambatan pertumbuhan dan akhirnya berdampak buruk bagi perkembangan mental intelektual individu. Kurang gizi pada fase cepat tumbuh otak akan bersifat ireversibel; artinya, kecerdasan anak tersebut tidak bisa lagi berkembang secara optimal. Ini jelas akan semakin menurunkan kualitas bangsa Indonesia. KEP pada masa anak akan menurunkan IQ, meyebabkan kemampuan geometrik rendah, dan anak tidak bisa berkonsentrasi secara maksimal. ${ }^{4}$ Perilaku gizi yang salah pada anak sekolah perlu mendapat perhatian. Misalnya, tidak sarapan pagi, jajanan yang tidak sehat di sekolah, kurang mengonsumsi sayuran dan buah, terlalu banyak mengonsumsi fast food dan junk food, terlalu banyak mengonsumsi zat makanan tambahan seperti pengawet, pewarna, dan penamabah rasa. $^{5}$

Anak yang menderita kurang gizi (stunted) berat mempunyai rata-rata IQ 11 point lebih rendah dibandingkan rata-rata anak-anak yang tidak menderita stunted. Lebih dari sepertiga (36,1\%) anak usia sekolah di Indonesia tergolong pendek ketika memasuki usia sekolah yang merupakan indikator adanya kurang gizi kronis. Prevalensi anak pendek ini semakin meningkat dengan bertambahnya umur dan gambaran ini ditemukan pada laki-laki maupun perempuan. ${ }^{8}$

Berdasarkan latar belakang tersebut maka peneliti tertarik untuk meneliti apakah ada hubungan antara status gizi dengan prestasi belajar pada anak.

\section{METODE PENELITIAN}

Penelitian ini merupakan penelitian deskriptif analitik dengan desain potong lintang. Penelitian ini bertempat di Sekolah Dasar yang berada di wilayah Kecamatan Modoinding Kabupaten Minahasa Selatan pada bulan November 2014 - Januari 2015.

Populasi penelitian ialah semua anak sekolah dasar di wilayah Kecamatan Modoinding Kabupaten Minahasa Selatan yang bersedia mengikuti penelitian. Sampel ialah anak yang berusia 8-12 tahun di Sekolah Dasar wilayah Kecamatan Modoinding Kabupaten Minahasa Selatan yang termasuk kriteria inklusi.

Analisis data dilakukan dengan analisis univariat dan analisis bivariat dengan uji statistik Anova berdasarkan variabel status gizi dan prestasi.

\section{HASIL PENELITIAN}

Penelitian ini dilaksanakan di Sekolah Dasar yang berada di wilayah Kecamatan Modoinding Kabupaten Minahasa Selatan dengan jumlah sampel sebanyak 114 anak

Tabel 1 menunjukkan dari 114 sampel, terdapat 59 siswa perempuan $(51,8 \%)$ dan 55 siswa laki-laki (48,2\%). 
Tabel 1. Jumlah Sampel Berdasarkan Jenis Kelamin

\begin{tabular}{ccc}
\hline Jenis Kelamin & Frekuensi & $\%$ \\
\hline $\mathrm{L}$ & 55 & 48,2 \\
$\mathrm{P}$ & 59 & 51,8 \\
Jumlah & 114 & 100,0 \\
\hline
\end{tabular}

Tabel 2 menunjukan dari 114 sampel yang terbanyak ditemukan ialah obesitas sebanyak 39 siswa (34,2\%) diikuti overweight 30 siswa $(26,3)$.

Tabel 2. Jumlah Sampel Berdasarkan Status gizi

\begin{tabular}{lll}
\hline & Frekuensi & $\%$ \\
\hline Kurang & 17 & 14,9 \\
Normal & 28 & 24,6 \\
Overweight & 30 & 26,3 \\
Obesitas & 39 & 34,2 \\
Jumlah & 114 & 100,0 \\
\hline
\end{tabular}

Berdasarkan Tabel 3, umur terendah ialah 8 tahun sedangkan yang tertinggi 12 tahun dengan rerata umur 9 tahun (SD \pm 1,10359). Berat badan yang terendah $17 \mathrm{~kg}$ sedangkan yang tertinggi $73 \mathrm{~kg}$ dengan rerata $33 \mathrm{~kg}(\mathrm{SD} \pm 9,77139)$. Tinggi badan yang terendah 102,80 cm sedangkan yang tertinggi 149,6 cm denan rerata tinggi badan 128,3096 (SD $\pm 9,15027)$. IMT yang terendah 11,39 sedangkan yang tertinggi 33,15 dengan rerata IMT 19,8711 $(\mathrm{SD} \pm 4,29891)$.

Berdasarkan Tabel 4 siswa dengan status gizi kurang mempunyai nilai rerata $68,53(\mathrm{SD} \pm 4,170)$. Siswa dengan status gizi baik (normal) mempunyai nilai rerata 68,96 (SD $\pm 5,366)$. Siswa dengan status gizi overweight mempunyai nilai rerata 69,88 $(\mathrm{SD} \pm 4,232)$. Siswa dengan status gizi obesitas mempunyai nilai rerata 69,38 (SD $\pm 4,960)$.

Tabel. 3. Nilai Minimum, Maximum, Mean, dan Standar Deviasi Umum, BB, TB, dan IMT

\begin{tabular}{ccccc}
\hline & Umur & BB & TB & IMT \\
\hline $\mathrm{N}$ & 114 & 114 & 114 & 114 \\
Minimum & 8,00 & 17,00 & 102,80 & 11,39 \\
Maximum & 12,00 & 73,00 & 149,60 & 33,15 \\
Mean & 9,2544 & 33,1623 & 128,3096 & 19,8711 \\
Std. Deviation & 1,10359 & 9,77139 & 9,15027 & 4,29891 \\
\hline
\end{tabular}

Tabel 4. Nilai Minimun, Maximum, Mean, Median, dan Standar Deviasi Status Gizi

\begin{tabular}{ccccccc}
\hline Status Gizi & N & Minimum & Maximum & Mean & $\begin{array}{c}\text { Std. } \\
\text { Deviation }\end{array}$ & Median \\
\hline Kurang & 17 & 63 & 78 & 68,53 & 4,170 & 68,00 \\
Normal & 28 & 57 & 81 & 68,96 & 5,366 & 69,00 \\
Overweight & 30 & 60 & 79 & 69,88 & 4,232 & 70,00 \\
Obes & 39 & 53 & 78 & 69,38 & 4,960 & 70,00 \\
Total & 114 & 53 & 81 & 69,29 & 4,735 & 69,50 \\
\hline
\end{tabular}

Tabel. 5. Pengujian Hubungan Status Gizi dengan Prestasi Belajar

\begin{tabular}{cccccc}
\hline & Sum of & & & & \\
& Squares & Df & Mean Square & F & Sig. \\
\hline Between Groups & 23,713 & 3 & 7,904 &, 346 &, 792 \\
Within Groups & 2509,772 & 110 & 22,816 & & \\
Total & 2533,485 & 113 & & & \\
\hline
\end{tabular}


Hasil uji hubungan antara status gizi dan prestasi belajar atau hasil uji perbedaan prestasi belajar menurut status gizi dengan Anova uji $\mathrm{F}$ menyatakan tidak terdapat hubungan bermakna antara status gizi dan prestasi belajar $(\mathrm{p}=0,792)$ atau tidak terdapat perbedaan bermakna prestasi belajar antara anak dengan status gizi kurang, normal, overweight, dan obesitas ( $\mathrm{p}$ $=0,792)$.

\section{BAHASAN}

Status gizi tampaknya berperan dalam menentukan prestasi belajar seorang siswa. Pemberian gizi yang kurang baik terutama terhadap anak-anak, akan menurunkan potensi sumber daya pembangunan masyarakat. Pemilihan nutrisi yang tepat akan mengoptimalkan pertumbuhan dan perkembangan otak. ${ }^{3}$ Terdapat beberapa penelitian yang menunjukkan bahwa status gizi berpengaruh pada prestasi belajar seperti pada salah satu jurnal Gizido ${ }^{8}$ menurut Depkes RI status gizi yang baik merupakan salah satu faktor penentu keberhasilan pembangunan indonesia. Gizi yang baik akan menghasilkan SDM yang berkualitas dan cerdas.

Telah dilakukan penelitian di sekolah dasar yang berada di wilayah Kecamatan Modoinding Kabupaten Minahasa Selatan. Sampel adalah anak Sekolah Dasar dengan usia 8-12 tahun yang bersedia mengikuti penelitian, dan tercatat sebanyak 114 sampel. Dari 114 sampel, terdapat 59 siswa perempuan dan 55 siswa laki-laki. Dari 114 sampel tersebut, diperoleh 17 siswa dengan status gizi kurang, 28 siswa status gizi baik atau normal, 30 siswa status gizi overweight, dan 39 siswa dengan status gizi obesitas.

Berdasarkan hasil uji diatas hubungan antara status gizi dan prestasi belajar atau hasil uji perbedaan prestasi belajar menurut status gizi, yang diuji dengan Anova uji F menyatakan tidak ada hubungan bermakna antara status gizi dan prestasi belajar ( $\mathrm{p}=$ 0,792) atau tidak ada perbedaan yang bermakna prestasi belajar antara anak dengan status gizi kurang, normal, overweight, dan obesitas ( $p=0,792)$. Hasil yang didapatkan berbeda dengan penelitian yang dilakukan oleh Legi ${ }^{8}$ yang mengatakan bahwa terdapat hubungan antara status gizi dan prestasi belajar siswa, yang didukung oleh pendapat Budiyanto bahwa tingkat keadaan gizi normal tercapai bila kebutuhan zat gizi optimal terpenuhi. ${ }^{8}$ Penelitian ini juga tidak sesuai dengan penelitian yang dilakukan oleh Ijarotimi dan Ijadunola $^{9}$ di Nigeria, yang mendapatkan bahwa pada anak kekurangan gizi akan terjadi perubahan pada metabolisme yang berdampak pada kemampuan kognitif dan kemampuan otak. Kurangnya asupan nutrisi pada anak akan berefek dalam membentuk dan menyimpan memori. ${ }^{9,10}$ Status gizi kurang menyebabkan kognitif dan perkembangan IQ terhambat serta kemampuan belajar terganggu yang selanjutnya berpengaruh pada prestasi belajar siswa. ${ }^{11}$

Berdasarkan hasil nilai $\mathrm{p}$ yang didapat yaitu $\mathrm{p}=0,792(\mathrm{p}>0,05)$ maka hipotesis H0 diterima. Menurut pendapat Supariasa, ${ }^{12}$ status gizi bukan hanya ditentukan dengan ukuran antropometri atau indeks massa tubuh, tetapi juga dapat ditentukan secara biokimia, yaitu pemeriksaan spesimen yang diuji secara laboratoris. Pada penelitian ini tidak dilakukan pemeriksaan secara biokimia sehingga tidak bisa dinilai status gizi anak secara spesifik antara lain adanya anemia defisiensi besi beserta gejalagejalanya. $^{13,14}$ Penurunan pemusatan perhatian, kecerdasan, dan prestasi dapat terjadi jika terdapat anemia defisiensi besi. $^{13}$

Hasil penelitian ini sesuai dengan penelitian Purba ${ }^{14}$ yang menyatakan tidak terdapat hubungan antara status gizi dengan prestasi belajar berdasarkan IMT/U. Hasil ini juga serupa dengan penelitian Annas ${ }^{15}$ yang menyatakan tidak ada hubungan bermakna antara status gizi dengan prestasi belajar. Hal ini menyatakan, bahwa prestasi belajar anak tidak hanya dipengaruhi oleh status gizi tapi juga bisa dipengaruhi oleh stimulasi dari orang tua serta sarana yang tersedia.

Perbedaan hasil penelitian ini mungkin disebabkan karena perbedaan populasi 
penelitian dan besarnya populasi. Selain itu, penilaian status gizi tidak hanya dapat ditentukan dengan antropometri tapi juga dapat dinilai berdasarkan uji laboratorium.

Dari hasil penelitian dapat disimpulkan bahwa siswa sekolah dasar di Modoinding lebih banyak yang obes dengan nilai rerata cukup.

\section{SIMPULAN}

Dari hasil penelitian di Kecamatan Modoinding dapat disimpulkan tidak terdapat hubungan antara status gizi dan prestasi belajar siswa sekolah dasar.

\section{SARAN}

Disarankan agar pihak sekolah dapat mempertahankan dan meningkatkan prestasi belajar para siswa.

Perlu dilakukan pengukuran status gizi secara periodik agar dapat mencegah status gizi buruk.

\section{DAFTAR PUSTAKA}

1. Suzeta PH. Rencana aksi nasional pangan dan gizi 2006-2010. Available from: http://ntt-academia.org/Pangantt/RANPangan-Nutrisi-Bahasa.pdf.

2. Hidayati RN. Hubungan Asupan Makanan Anak dan Status Ekonomi Keluarga dengan Status Gizi Anak Usia Sekolah di Kelurahan Tugu. Keperawatan Bina Sehat. 2012;7:1-7.

3. Devi N. Tentukan Masalah Gizi Anak Sekolah. In: Gizi Anak Sekolah. Jakarta: Kompas, 2012; p.13.

4. Ali AR. Perbedaan Kadar Hb, Status Gizi dan Prestasi Belajar Anak SD Wilayah Pantai dan Pegunungan di Kab. Polewali Mandar Tahun Ajaran 2005/2006. 2008:1-3.

5. Devi N. Kebutuhan Gizi Anak Sekolah. In: Gizi Anak Sekolah. Jakarta: Kompas, 2012; p. 47.

6. Agustini C, Malonda NS, Purba RB. Hubungan Antara Status Gizi dengan
Prestasi Belajar Anak Kelas 4 dan 5 Sekolah Dasar di Kelurahan Maasing. Available from:

http://fkm.unsrat.ac.id/wpcontent/uploads/2013/08/creisyecynthia-agustini.pdf.

7. Riset Kesehatan Dasar (RISKESDAS) 2010. Available from: http: //www.litbang.depkes.go.id/sites/downl oad/buku_laporan/lapnas_riskesdas201 0/Laporan_riskesdas_2010.pdf.

8. Legi NN. Hubungan status gizi dengan prestasi belajar siswa Sekolah Dasar Negeri Malalayang Kecamatan Malalayang. Gizido. 2012;4:312-26.

9. Ijarotimi OS, Ijadunolo KT. Evaluation of energy and micronutrients intake with learning achievement at Nigerian. Journal of Nutrition. 2007;3(4) 250-3.

10.Saadah RH, Herman RB, Sastri S. Hubungan status gizi dengan prestasi belajar siswa sekolah dasar negeri 01 Guguk Malintang Kota Padang panjang. Andalas;2014:3(3).

11.Sorhaindo A, Feinstein L. Relationship between child nutrition and school outcomes. London: Center for research on the Wider Benefits of Learning Institute of Education, 2006.

12.Supriasa IDN. Penilaian Status Gizi. Jakarta: EGC, 2002.

13.Minatun S. Faktor-faktor yang berhubungan dengan prestasi belajar siswa kelas IV dan V MI Cempaka Putih Ciputat Timur tahun ajaran 2010/2011 [Skripsi]. Jakarta: Universitas Islam Negeri Syarif Hidayatullah, 2011.

14.Purba RB. Hubungan kecerdasan emosional, status gizi dengan prestasi belajar [Tesis]. Semarang: Universitas Diponegoro, 2010.

15.Annas M. Hubungan kesegaran jasmani, hemoglobin, status gizi, dan makan pagi terhadap prestasi belajar. Jurnal Media Ilmu Keolahragaan Indonesia. 2011;1(2):192-6. 